\title{
Application of the D-A-(C) index as a simple tool for microbial-ecological characterization and assessment of groundwater ecosystems - a case study of the Mur River Valley, Austria
}

\author{
Alice Retter · Christian Griebler · Johannes Haas · Steffen Birk · Christine Stumpp · Heike Brielmann • \\ Lucas Fillinger
}

Accepted: 9 August 2021 / Published online: 16 September 2021

(C) The Author(s) 2021

\begin{abstract}
The assessment and monitoring of the ecological quality and status of groundwater is a timely issue. At present, various assessment tools have been developed that now await application and validation. One of these, the D-A-C index, evaluates the microbiological-ecological quality of groundwater based on of prokaryotic cell counts, microbial activity measurements, and the qualitative characterization of dissolved organic carbon (DOM). The purpose of this paper is to illustrate the different ways of application of the D-A-(C) index making use of a recently collected data set $(n=61)$ from the river Mur valley, Austria. First, we present an extension of the D-A-(C) index by including measurements of dissolved organic matter quality (DOM) derived from fluorescence spectroscopy as ad-
\end{abstract}

\section{A. Retter, BSc MSc. . \\ Univ.-Prof. Mag. Dr. C. Griebler . Dr. L. Fillinger, BAS, MSc ( $\triangle)$ Department of Functional and Evolutionary Ecology, University of Vienna, Althanstraße 14, 1090 Vienna, Austria \\ lucas.fillinger@univie.ac.at}

Dr. J. Haas · Univ.-Prof. Dr. S. Birk NAWI Graz Geocenter, Institute of Earth Sciences, University of Graz, Universitätsplatz 3, 8010 Graz, Austria

Univ.-Prof. Dr. C. Stumpp Institute for Soil Physics and Rural Water Management, University of Natural Resources and Life Sciences (BOKU), Gregor-Mendel-Straße 33, 1180 Vienna, Austria

DI Dr. H. Brielmann

Environment Agency Austria, Spittelauer Lände 5, 1090 Vienna, Austria ditional variables to supplement the analysis of microbial cell density and activity levels. Second, we illustrate how the definition of a reference status for a 'good' microbiological-ecological state can improve the analysis and allow for a more sensitive and accurate detection of impacts on groundwater ecosystems. Based on our results, we advocate that the analysis be performed by making use of expert knowledge for the definition of reference sites to which target sites are to be compared.

Keywords Aquifer - Surface water . Ecological monitoring · Ecosystem health - Microbial total cell counts . Microbial intracellular ATP · Dissolved organic matter fluorescence spectroscopy

\section{Anwendung des D-A-(C)-Index als einfache Methode zur mikrobiologisch-ökologischen Charakterisierung und Überwachung von Grundwasserökosystemen - eine Fallstudie anhand des österreichischen Murtals}

Zusammenfassung Die Bewertung und Überwachung des ökologischen Zustands von Grundwasser ist zunehmend von zentraler Bedeutung. Innerhalb der letzten Jahre wurde eine Anzahl verschiedener Ansätze entwickelt, deren Anwendung und Validierung in der Praxis jedoch derzeit weitestgehend noch aussteht. Einer dieser Ansätze ist der D-A-(C)-Index, der es ermöglicht, anhand der prokaryotischen Gesamtzellzahl, mikrobiellen Aktivität und Konzentration oder Qualität des gelösten organischen Materials (DOM) den mikrobiologisch-ökologischen Zustand des Grundwassers zu erfassen. Das Ziel unserer Studie war es, unterschiedliche
Anwendungsmöglichkeiten des D-A(C)-Index anhand kürzlich erhobener Daten $(n=61)$ aus dem österreichischen Murtal zu illustrieren. Des Weiteren stellen wir eine Erweiterung des D-A-(C)-Index vor, bei der zusätzlich zur mikrobiellen Gesamtzellzahl und Aktivität die mittels Fluoreszenzspektroskopie gemessene Qualität des gelösten organischen Materials in die Bewertung mit einbezogen wird. Darüber hinaus wird veranschaulicht, wie durch die Definition einer Referenz für einen „guten“ mikrobiologisch-ökologischen Zustand die Sensitivität und Genauigkeit zur Erfassung von ökologischen Störungen weiter erhöht werden kann. Anhand unserer Ergebnisse sprechen wir die Empfehlung aus, dass vorhandenes Expertenwissen und Vorkenntnisse über die lokalen Gegebenheiten die Grundlage für die Bestimmung von geeigneten, repräsentativen Referenzmessstellen bilden sollten.

Schlüsselwörter Grundwasserkörper . Aquifer · Oberflächengewässer · Ökosystemüberwachung · Mikrobielle Gesamtzellzahl · Mikrobielles intrazelluläres ATP · Gelöstes organisches Material . Fluoreszenzspektroskopie

\section{Introduction}

Besides being a vital resource, groundwater is the largest, yet still mostly unexplored freshwater ecosystem on our planet, harboring a rich diversity of microbial and metazoan life (Gibert and Culver 2009; Griebler and Lueders 2009). These organisms are key to ecosystem services provided by groundwater, including, among many others, the attenuation of anthropogenic contaminants and pathogens (Griebler and Avramov 2015; Herman et al. 2001). 
Such ecosystem services are directly linked to human welfare and the health of all groundwater-dependent ecosystems (Griebler et al. 2014a). At about $20-30 \%$ of the global land surface, shallow groundwater feeds surface waters, wetlands and the roots of plants (Ribeiro et al. 2013). These shallow groundwater bodies are particularly vulnerable to impacts from the surface such as hydrometeorological changes, rising sea water levels, as well as anthropogenic pressures like intensive agriculture (Khan et al. 2018; Lee et al. 2019; Menchen et al. 2017), industrial activities (Brielmann et al. 2009; Rehman and Cheema 2016; Singh et al. 2016), and urbanization (Hassane et al. 2016; Howard and Gerber 2018; Minnig et al. 2018). In addition, surface waters that receive wastewater and are subject to hydrological extremes such as flood events may carry pollutants from the surface into aquifers, thereby seriously compromising groundwater quality (Corada-Fernández et al. 2017).

It is these shallow groundwater systems that are also of greatest ecological interest. Shallow groundwater bodies are more likely to receive sufficient energy from the surface (mostly in the form of dissolved organic matter $(\mathrm{DOM})$ ) to sustain active microbial and metazoan communities, and are therefore home to most of the biodiversity found in groundwater habitats (Hubalek et al. 2016; Ward et al. 2017). However, despite early reports on groundwater biodiversity (Spandl 1926), until recently groundwater was primarily viewed as a commodity in the eyes of policymakers, with little consideration for groundwater biodiversity and ecosystem health (Griebler et al. 2010). Yet, the conservation and protection of groundwater as a unique habitat forms the basis for maintaining its diverse ecological functions on which mankind is ultimately highly dependent (e.g. water provided for drinking, irrigation, industrial processes) (Griebler and Avramov 2015).

Legal guidelines for groundwater monitoring have almost exclusively focused on the assessment of physicochemical and hygienic parameters, whereas frameworks demanding assessments of ecological parameters, comparable to those defined for surface water ecosystems including the EU Water Framework Directive (EU WFD, 2000/60EC, European Commission 2000), have long been lacking.
Yet, policymakers in different parts of the world have started to become increasingly aware of the inextricable link between groundwater quality and ecosystem health, which has led to new environmental directives incentivizing the incorporation of ecological parameters in routine groundwater monitoring practices. Prominent examples of such directives come from Switzerland and Australia, as well as the EU (SWPO 1998; NSW-SGDEP 2002; EPA 2003; EU-GWD 2006). Despite these developments, ecological assessments have not been widely implemented in routine groundwater monitoring so far, because reliable and validated monitoring criteria and tools have long been unavailable.

Recent research efforts have started to fill this gap by developing practically applicable toolboxes and assessment schemes that target the different biological facets of groundwater ecosystems ranging from microorganisms to metazoan groundwater fauna (Hahn 2006; Steube et al. 2009; Korbel and Hose 2011, 2017; Griebler et al. 2014b; Di Lorenzo et al. 2020; Hose et al. 2021). Prokaryotic microorganisms are particularly suited as monitoring targets in groundwater ecosystems, as they are ubiquitous and occur under environmental conditions that exclude metazoan fauna, such as naturally anoxic groundwater. We have recently developed the D-A-(C) index (in German termed B-A-(E) Index) as an approach to detect biological disturbances of groundwater ecosystems based on the microbial parameters cell density (D), activity (A) measured as intracellular ATP levels, and, the quantity and/or quality of organic carbon (C) as an optional parameter (Griebler et al. 2018; Fillinger et al. 2019). The D-A(C) index combines all parameters in a multivariate outlier analysis yielding a single index value that flags individual outlier samples in a dataset as potentially ecologically disturbed. One of the main advantages of this approach is that its parameters are fast and easy to measure and its universal applicability is independent from environmental conditions. Furthermore, the multivariate nature of the approach allows for fully exploiting the data of the measured parameters, and we showed that it enables a more robust and sensitive detection of outliers indicative of ecological disturbances in groundwater compared to univariate outlier analyses applied to each microbiological param- eter separately (Fillinger et al. 2019). As an additional advantage, the D-A(C) index can be easily extended by additional variables, without compromising the simplicity of the analysis, as the signals of multiple parameters are integrated into a single index value that is easy to interpret. For instance, we previously showed how concentrations of microbially assimilable organic carbon (AOC) derived from batch incubation assays (Hammes and Egli 2005) can increase the sensitivity for detecting impacts from agricultural land use on groundwater ecosystems (Fillinger et al. 2019).

The detection of an ecological disturbance, as well as the assessment of the groundwater ecosystem condition into 'good' or 'impaired', depends critically on the definition of a regional or even local reference. Yet, due to the heterogeneous nature of groundwater ecosystems, defining a 'good' ecological reference status can be challenging. To date, the definition of such references has been severely hampered by the lack of robust and long-term datasets on key ecological variables. For this study, we analyzed a dataset that covers key parameters that are easy to come by, i.e., excluding molecular methods. These consisted of microbiological, physicochemical, and hydrological information of 46 groundwater samples, 13 river water samples, and 2 samples from springs, collected all along the Austrian part of the river Mur, from its highly alpine origin $(\sim 2000 \mathrm{~m}$ asl (above sea level)) to its exit to Slovenia $(\sim 200 \mathrm{~m}$ asl). Criteria considered in these analyses include the individual water types, sub-regions (combining information on groundwater bodies and geology), and possible land use impacts, among others. This study strives to assess how the definition of a natural reference groundwater status affects the outcome and sensitivity of the D-A (C) analysis. In other words, the reliable assessment of the microbiological-ecological quality of groundwater and the extent to which groundwater systems are 'impaired' largely depends on what is defined as an intra-regional pristine reference status. The aim is to determine the natural state of groundwaters within each sub-region, to detect intra-regional outliers, and to explore possible reasons for disturbances (e.g., influence of groundwater-surface water interactions) based on this extensive data set. 
Furthermore, we explored the usefulness of DOM quality indices derived from fluorescence spectroscopy as promising additional parameters to be included in the D-A- $(\mathrm{C})$ index. Fluorescence spectroscopy of DOM has previously been used mainly to examine shifts in DOM composition in surface water systems with season, changing environmental conditions, or in response to anthropogenic impacts, (Benk et al. 2019; Coble et al. 2014; Harjung et al. 2020). Moreover, it has been used to study risks of fecal contamination in groundwater and drinking water systems (Frank et al. 2018; Nowicki et al. 2019; Sorensen et al. 2015, 2020). Fluorescence spectroscopy of DOM is simple and inexpensive, and thus DOM indices are highly suitable for the incorporation into routine monitoring practices. Ohno (2002) and Huguet et al. (2009) have introduced two indices for the characterization of fluorescent DOM, i.e. the humification index (HIX) and the biological index (BIX). HIX provides information on the degree of humification of DOM, while BIX represents the degree of freshly produced, autochthonous, protein-like DOM. Due to the typically low biological productivity of oligotrophic groundwater environments, the bulk of the DOM is usually composed of recalcitrant, humic compounds derived from the surface with a comparatively small contribution of fresh microbially produced DOM (Gooddy and Hinsby 2009; Hofmann et al. 2020; Shen et al. 2015). Furthermore, we hypothesize that in general the increased inputs of organic matter from the surface can cause changes in groundwater DOM quality either directly, or indirectly via the stimulation of biological productivity. This can be caused, for example, by intensive agriculture (e.g., application of manure) or heavy rain events that cause pulses of DOM passing to shallow aquifers through seepage water. Therefore, combining information on DOM quality with information on prokaryotic cell densities and microbial activity can be a promising avenue for further increasing the sensitivity of the D-A- $(C)$ index approach.

Finally, to demonstrate the versatility and sensitivity, as well as the limitations of the D-A-(C) index, the dataset at hand comprising microbiological, physico-chemical, and hydrological data was analyzed in three different ways: (1) using an unguided approach where we did not make any assumptions about the ecological condition of the groundwater, but simply calcu- lated the D-A-(C) index based on the full dataset regardless of location, or land use categories; (2) the data were analyzed at the resolution of sub-region and land use type to take into account regional differences within the data; and finally (3) we illustrate a case where prior expert knowledge of sites (information on reference is available) is used to guide the analysis.

\section{Materials and methods}

\subsection{Site description and sample collection}

The sampling was conducted in the federal provinces of Styria and Salzburg, Austria, during a five-week sampling campaign from June to July 2020. Samples $(n=61)$ were collected from groundwater wells, springs, and from the Mur River, as well as two tributaries, spanning a distance of around $300 \mathrm{~km}$ and an altitude gradient of around $1800 \mathrm{~m}$ (Fig. 1). The river Mur passes through the southeastern part of the province of Salzburg, with its spring located at approximately $2000 \mathrm{~m}$ asl, and through most of Styria, until it passes the Slovenian Border at around $200 \mathrm{~m}$ asl. Over this course, it passes through differing geological and morphological

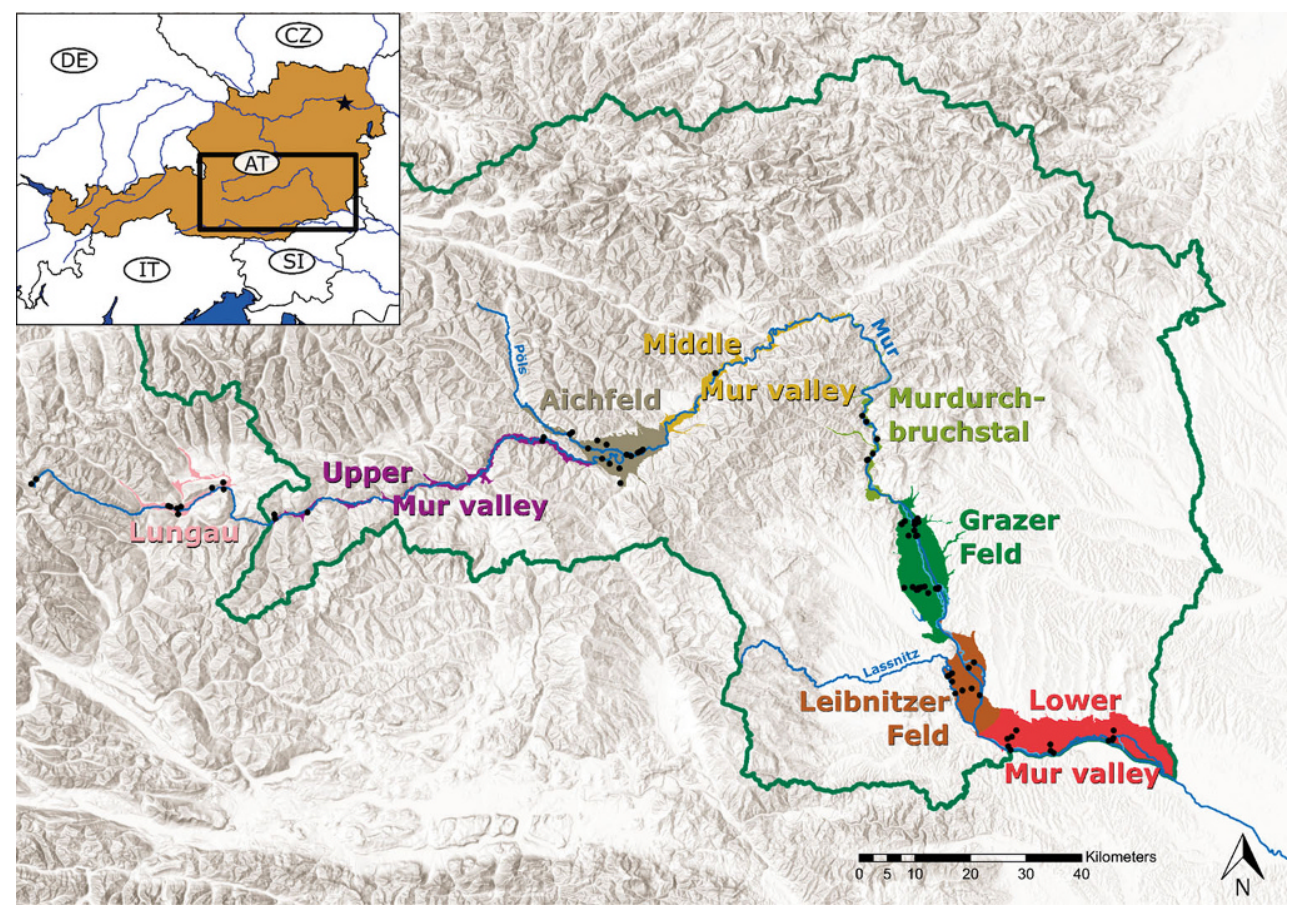

Fig. 1 Location of the study area within Styria (green boundaries), and Salzburg, as well as the sub-regions within the Mur valley (The Upper Mur valley, Lungau, Aichfeld, Middle Mur valley, Murdurchbruchstal, Grazer Feld, Leibnitzer Feld, and Lower Mur valley). The position of sampling sites of groundwater and surface water along the river Mur and its tributaries is indicated by black dots 
settings as well as different aquifers distinguished into eight groundwater bodies, in the following termed sub-regions.

From the border of the Tauernwindow at its origin, the river Mur passes through various-mostly metamorphic-units of the Austroalpine nappes until it reaches Neogene sediments south of the city of Graz as well as in some of the inner alpine basins, most notably in the Aichfeld. The aquifers following the river Mur are (glacio) fluvial valley fillings, mostly comprised of gravel and sand, locally with bodies of alluvial fan or rockslide sediments. The transversal and vertical dimensions of the Mur valley aquifers range from narrow valleys (e.g., the Murdurchbruchstal, where the valley is sometimes only a few hundred meters wide), to deep and wider, inneralpine basins, and finally broad but shallow foreland basins (Fig. 1). Alpine glaciations played a considerable role for the formation of the aquifers, either directly due to the glaciation of the approximately upper third of the Mur valley upstream of the Aichfeld or indirectly by the formation, erosion, and resedimentation of terraced sediments in most of the downstream aquifers. The investigated region of the Mur valley can therefore be divided into eight subregions (Fig. 1), roughly correspond to the delineated groundwater bodies characterized by different hydrological and geological settings (Haas and Birk 2017).

The study area covers different land use types, which include areas of intense agriculture in the Alpine foreland in the south of Styria, the industrial and commercial areas south of and around the city of Graz, urban areas in Graz, as well as sites used mainly for forestry and grassland farming in the peripheral mountainous and alpine regions of Styria and Salzburg. The land use types were classified into three levels using the Digital Atlas of the Province of Styria, which makes use of the CORINE Land Cover Database from 2018 (www. landesentwicklung.steiermark.at/cms/ beitrag/12723062/142970647/). The lowest level of characterization in the CORINE data base was used for further evaluation of the data (i.e., agricultural area, urban area, and forest and seminatural area). Most of the groundwater wells sampled in this study fall into the category 'Agricultural use' (30 sites), and each of the sub-regions contain some groundwater sites of this type of classification. 'Forests and semi-natural areas' (6 sites) were only covered by wells belonging to the lower Mur valley, Lungau (including the Mur source in the Hohe Tauern mountains), and one well in the Murdurchbruchstal. The category 'Urban areas' (12 sites) included wells in the lower Mur valley, Grazer Feld, and Aichfeld.

\subsection{Groundwater sampling}

Groundwater was sampled from already existing observation wells, which were installed within the last decades by the provinces of Styria and Salzburg for the purpose of groundwater quality and quantity monitoring. Therefore, for almost all the sampled groundwater wells long-term data series on hydraulic head (groundwater table) and temperature are available (www.ehyd.gv.at). Prior to our study, these long-term monitoring data were used to select appropriate spots and wells to be sampled in the different sub-regions. Groundwater was withdrawn by a Grundfos submersible MP1 pump (Eijkelkamp Soil \& Water, Giesbeek, Netherlands) which was placed 2 meters below the groundwater table. The pumping rate was set to allow a maximum drawdown of the water level of $0.5 \mathrm{~m}$. Before sample collection, stagnant well water was purged by pre-pumping twice the well water volume until reaching stability in key physico-chemical parameters (EC (Electric Conductivity), pH, Temperature, DO (Dissolved Oxygen)). Water temperature, $\mathrm{pH}$, electrical conductivity (EC), and concentration of dissolved oxygen (DO) were measured on-site using field sensors (WTW, Weilheim, Germany). During subsequent sample collection, the pumping rate was reduced to avoid dislodgement of microbial biofilms and withdrawal of fine sediments.

Groundwater, and surface water samples for the determination of microbial ATP, concentration of major ions, and stable water isotope ratios were filled into autoclaved glass bottles. For total prokaryotic cell counts, samples were collected in sterile $15 \mathrm{~mL}$ Falcon tubes and fixed with $0.5 \%(\mathrm{v} / \mathrm{v}$, final concentration) glutardialdehyde on-site. Samples for DOC measurement were filtered through a $0.45 \mu \mathrm{m}$ PVDF syringe filter (STARLAB International, Hamburg, Germany) into acidwashed $(5 \% \mathrm{HCl})$ glass vials and were immediately acidified to a $\mathrm{pH} \leq 2$ with
HCl. Samples for fluorescence spectroscopy of DOM were passed through a baked $0.7 \mu \mathrm{m}$ glass fiber filter (Whatman GF/F; GE Healthcare Life Sciences, Little Chalfont, UK) into pre-combusted glass vials $\left(450^{\circ} \mathrm{C}, 4 \mathrm{~h}\right)$. All samples were kept in the dark at below $4-8^{\circ} \mathrm{C}$ until further analysis.

\subsection{Laboratory analyses}

\subsubsection{Determination of total prokaryotic cell counts (cell density, D)}

The total number of prokaryotic cells was quantified using an Amnis CellStream Flow Cytometer (Luminex, Austin, TX, USA) equipped with a $488 \mathrm{~nm}$ blue light laser. Settings of the different detector channels were as follows: forward scatter, side scatter, trigger channel laser $(488 \mathrm{~nm})$ all at $100 \%$, speed 'high' (14.64 $\left.\mu \mathrm{L} \mathrm{min}{ }^{-1}\right)$, recording everything, and counting the gated area depending on the nature of the water sample (e.g., groundwater has a low cell density with usually only a few hundred events $\mathrm{sec}^{-1}$, whereas surface water can have up to a few thousand events $\sec ^{-1}$ ), but measuring for a minimum of $10 \mathrm{sec}$. If necessary, samples with more than 2000 events $\sec ^{-1}$ were diluted. To distinguish intact prokaryotic cells from damaged cells or inorganic particles, prokaryotes were stained with SYBR Green I nucleic acid stain (Invitrogen, Darmstadt, Germany) at a volume ratio of $1: 10000$ and incubated for $13 \mathrm{~min}$ at $37^{\circ} \mathrm{C}$. Cell counts were conducted in technical duplicates. Each replicate was measured at three different settings for events $\mathrm{sec}^{-1}$ (e.g., 100, 500 and 1000 for groundwater samples). Total cell counts (Cells $\mathrm{mL}^{-1}$ ) were calculated using the Amnis CellStream Acquisition and Analysis software.

\subsubsection{Determination of microbial intracellular ATP (activity, A)}

Microbial intracellular ATP concentrations were determined using the BacTiter-Glo Microbial Cell Viability Assay (Promega, Madison, WI, USA) based on the protocol by Hammes et al. (2010) with modifications as follows. The assay reagent (prepared following the manufacturer's instructions) and samples were pre-warmed separately to $37^{\circ} \mathrm{C}$ for $3 \mathrm{~min}$ before mixing $180 \mu \mathrm{L}$ of sample with $20 \mu \mathrm{L}$ of reagent in a 96 well plate. The plate was incubated for $20 \mathrm{sec}$ at $37^{\circ} \mathrm{C}$ while shaking at 
$600 \mathrm{rpm}$ in on Thermomixer (Eppendorf). The luminescence signal was measured in a GloMax Navigator plate reader (Promega) with an integration time of $0.3 \mathrm{sec}$. Concentrations were determined against external ATP standards dissolved in ATP-free water. To correct for the contribution of extracellular ATP in the samples, each sample was measured in two separate fractions, one fraction of the sample was centrifuged for $30 \mathrm{~min}$ at $21000 \times g$ and $4{ }^{\circ} \mathrm{C}$ to spin down cells such that the resulting supernatant contained only extracellular ATP. A second fraction was not centrifuged to obtain the total ATP concentration in the sample. The concentration of intracellular ATP was calculated by subtracting the concentration of extracellular from total ATP. Each sample fraction was analyzed in technical triplicates.

\subsubsection{Determination of DOC concentrations and DOM fluorescence spectroscopy (carbon, C)}

DOC concentrations were measured with a TOC-L Analyzer (Shimadzu, Kyoto, Japan), using a $25 \mathrm{ppm}$ TOC calibration curve standard, and additionally measuring MilliQ water, as well as control samples with a defined DOC concentration for quality control.

DOM fluorescence spectra from water samples were captured in an Aqualog spectrofluorometer (Horiba Scientific, Kyoto, Japan) using a quartz cuvette with a $1 \mathrm{~cm}$ optical path length and the Aqualog software version 3.6. Emission spectra were recorded from 212.53 to $621.80 \mathrm{~nm}$ at $1.64 \mathrm{~nm}$ increments at excitation wavelengths from 230 to $480 \mathrm{~nm}$ ( $4 \mathrm{~nm}$ increments) with an integration time set to $3 \mathrm{sec}$. Samples were measured against MilliQ water as a blank to subtract water Raman fluorescence peaks and convert fluorescence intensities to Raman units normalized relative to Raman scattering band intensity. The two DOM indices HIX and BIX were calculated from the EEM matrices according to Ohno (2002) and Huguet et al. (2009) based on Eq. 1 and 2, respectively:

$$
H I X=\frac{\sum\left(I_{E x: 254 n m ; E m: 435 n m \rightarrow 480 n m}\right)}{\sum\left(I_{E x: 254 n m ; E m: 300 n m \rightarrow 345 n m}\right)}
$$

where $I$ is the fluorescence intensity summed over the indicated range of emission wavelengths measured at excitation wavelength of $254 \mathrm{~nm}$.

$$
B I X=\frac{I_{E x: 310 n m ; E m: 380 n m}}{I_{E x: 310 n m ; E m: 430 n m}}
$$

where $I$ is the fluorescence intensity at the indicated excitation-emission wavelength. Normalization of fluorescence spectra and computation of HIX and BIX were done in $\mathrm{R}(\mathrm{v}$ 4.0.3; R Core Team, 2020) using the 'staRdom' package (v 1.1.14; Pucher et al. 2019).

\subsubsection{Stable water isotope measurements and determination of hydrochemical parameters}

Water samples were analyzed for ratios of ${ }^{18} \mathrm{O} /{ }^{16} \mathrm{O}$ and ${ }^{2} \mathrm{H} /{ }^{1} \mathrm{H}$ using laser spectroscopy (Picarro, L2140-i). All samples were referenced to the VSMOW-SLAP (Vienna Standard Mean Ocean WaterStandard Light Antarctic Precipitation) scale, and results are reported as the ratios of isotopes in the delta notation as $\delta$-value $(\%)$. Precision of the instrument $(1 \sigma)$ was better than $0.15 \%$ and $0.6 \%$ for $\delta^{18} \mathrm{O}$ and $\delta^{2} \mathrm{H}$.

Major ion concentrations $\left(\mathrm{Na}^{+}, \mathrm{K}^{+}\right.$, $\left.\mathrm{Ca}^{2+}, \mathrm{Mg}^{2+}, \mathrm{Cl}^{-}, \mathrm{SO}_{4}{ }^{2-}\right)$ were measured by ion chromatography (Dionex ICS1100 RFIC; Thermo Scientific, Idstein, Germany) following standard norms (OENORM DIN EN ISO 14911, DIN EN ISO 10304-1). $\mathrm{NO}_{3}{ }^{-}$and $\mathrm{NH}_{4}{ }^{+}$concentrations were determined by photometric measurements (UV-method in the filtrate $(\lambda=220 \mathrm{~nm})$; APHA $4500-\mathrm{NO} / \mathrm{B}$, and Indophenol blue method in filtrate $(\lambda=655 \mathrm{~nm})$ : DIN 38406-5, OENORM ISO 7150-1).

\subsubsection{Determination of the MWWI}

The indicator test for municipal wastewater (MWWI) is based on the presence/ absence of selected typical municipal waste water-derived compounds, i.e. acesulfame, tolyltriazoles, carbamazepine, benzotriazole, sotalol, metoprolol, 10,11-dihydro-10,11-dihydroxycarbamazepine (CBZ-DiOH) and diclofenac. All compounds were measured by direct injection in a LCMS/MS system (Waters Xevo TQS) using a Waters Acquity UPLC BEH C18 $1.7 \mu \mathrm{m} 2.1 \times 50 \mathrm{~mm}$ column and MilliQ water with $0.1 \%$ HFA as eluent. Acesulfame was analyzed in negative mode, while benzotriazole, carbamazepine, 10,11-dihydro-10,11-dihydroxycarbamazepine (CBZ-DiOH), diclofenac, metoprolol, sotalol and tolyltriazole were analyzed in positive mode. Based on the comparison of measured concentrations with mean concentrations of these compounds in waste water effluents and literature values, the municipal wastewater index (MWWI) classified samples into 4 categories (0-no influence, 1-influence unlikely, 2-influence likely, 3-influenced by municipal waste water).

\subsection{Data analysis}

Essentially, the D-A-(C) index is based on a multivariate outlier analysis. Under normal undisturbed conditions, samples are expected to display a certain distribution in a multivariate space along the variables included in the analysis. For multivariate normally distributed data, a cloud of samples arrange in an elliptical form, which is defined by the mean values of the variables forming the center of the ellipse, and the covariance matrix determining its shape and slope. A disturbance that causes severe changes in one or more of these variables increases the distance of the affected sample to the center of the ellipse beyond the range of distance expected due to random variation. In other words, samples affected by a disturbance can be considered outliers. The distance of a single sample $i$ to the center of the multivariate distribution is calculated as the Mahalanobis distance $(M D)$ according to Eq. 3:

$$
M D_{i}=\sqrt{\left(X_{i}-\mu\right)^{\prime} \times S^{-1} \times\left(X_{i}-\mu\right)}
$$

where $X_{i}$ is a vector with the values of the individual D-A-(C) variables for a single sample, and $\mu$ and $S^{-1}$ are the vector with variable means and the inverse of the covariance matrix, respectively, calculated from the full dataset.

Because $M D$ takes values of the square root of chi-squared distribution with as many degrees of freedom as variables included in the analysis (e.g. $\mathrm{df}=2$ if only microbial cell density and activity are included), statistical thresholds for $M D$ can be defined above which a sample is considered a significant outlier at a given confidence level. For instance, $97.5 \%$ of the values of a chi-squared distribution with $\mathrm{df}=2$ are $<7.38$. Hence a sample with $M D$ larger than the critical value of in a twoparameter analysis would be declared an outlier at a 0.975 confidence level. 


\section{Originalarbeit}

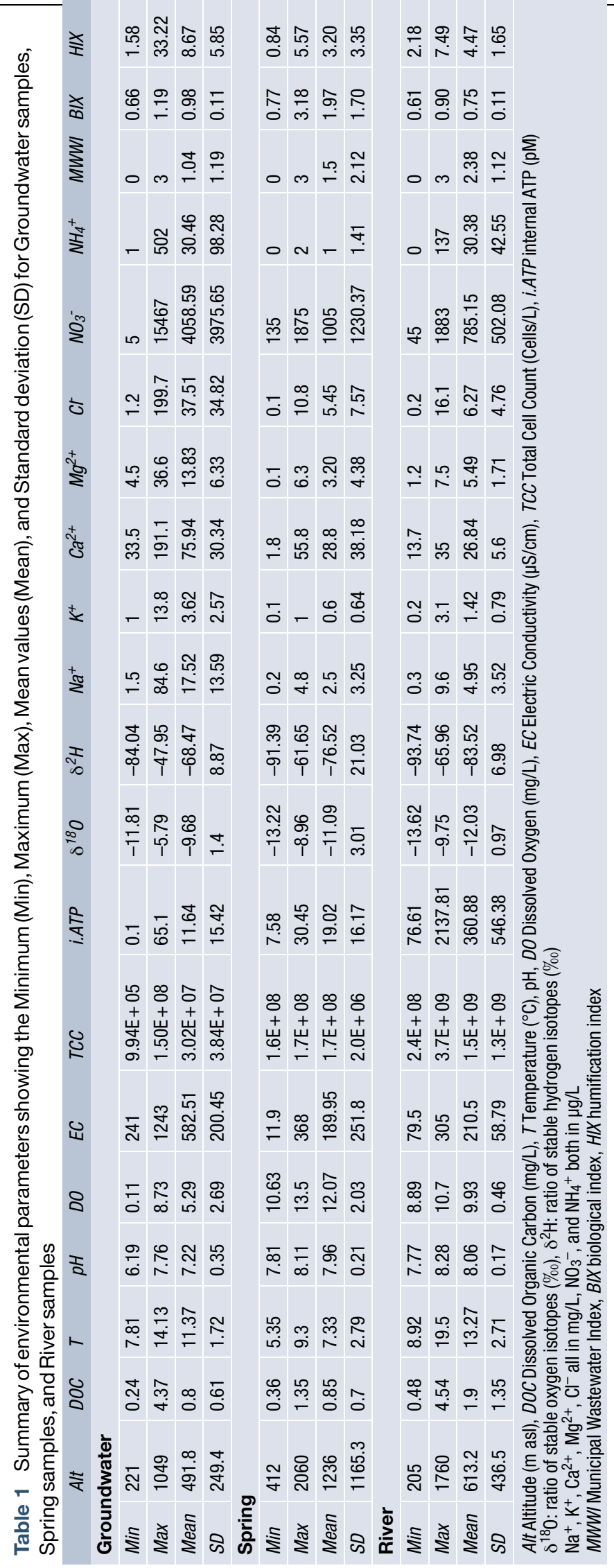



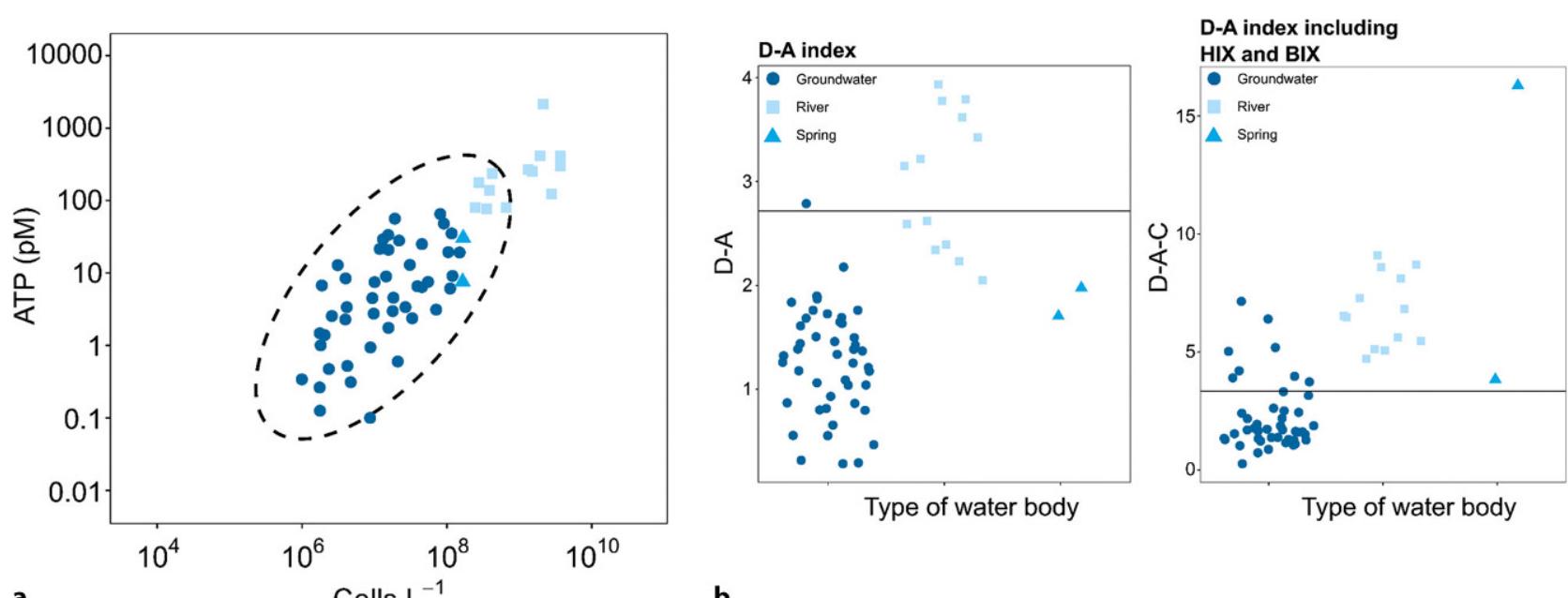

a Cells $\mathrm{L}^{-1}$

b
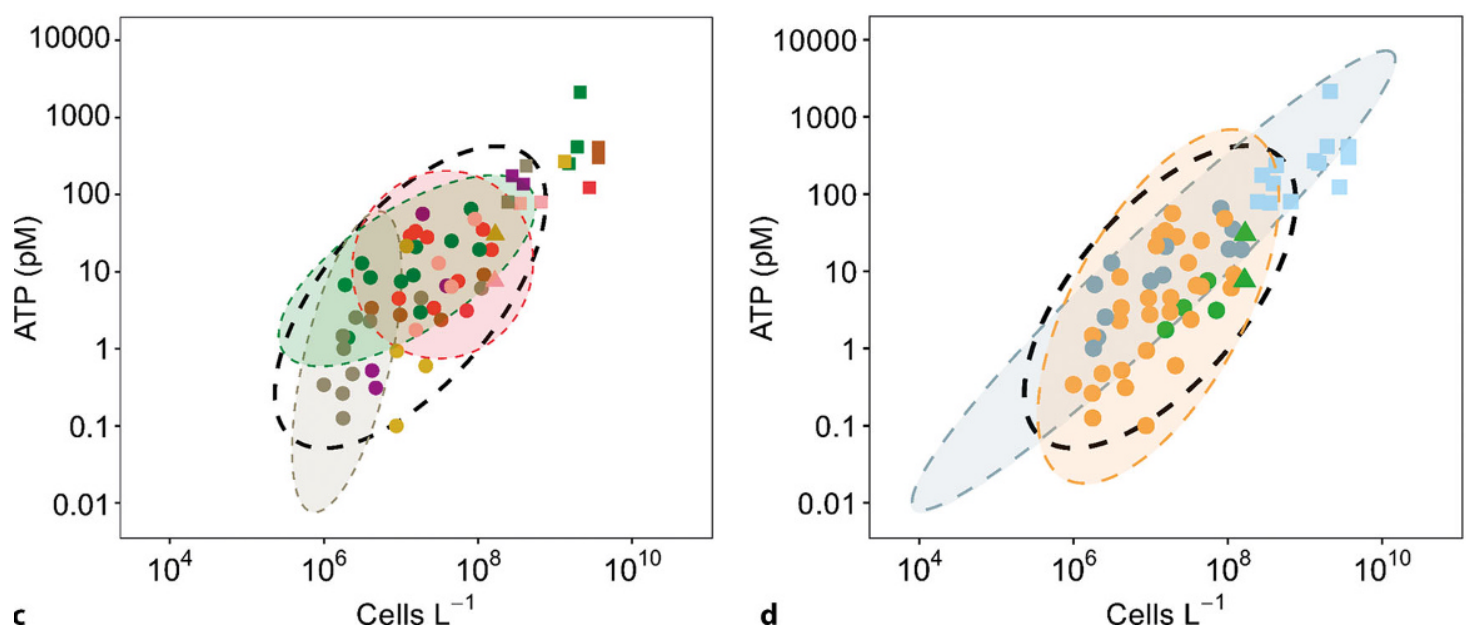

$\square$ River

O Groundwater

$\triangle$ Spring

Agricultural areas

Forests and seminatural areas

- Urban areas

- Aichfeld

- Grazer Feld

- Leibnitzer Feld

- Lungau

- Murdurchbruchstal

- Upper Mur Valley

- Lower Mur Valley

Fig. 2 Bivariate plot of internal ATP, and microbial cell counts shown in a, c, and d, depicting the mean values of the random variation within the ground water dataset as a black, dashed 0.975 confidence ellipse, as well as showing the respective groups (type of waterbody (a), sub-regions (c), and land use (d)); 0.975 confidence ellipses in the groups corresponding color. (b) shows the D-A Index (left), and D-A-C Index (right) that are computed according to approach 1 without prior knowledge, mean and covariance based on the groundwater dataset, but calculated for all samples. The solid black vertical line depicts the critical value of the chi-squared distribution with a confidence level of 0.975 and two degrees of freedom (D-A) and four degrees of freedom (D-A-C), and the x-axis shows the data points fanned out into the various water types

However, calculating $M D$ from a full set of raw data directly is problematic, because outliers present in the data can severely distort the estimates of mean values $(\mu)$ as well as variance and covariance $(S)$ of the data. To overcome this problem, the D-A- $(\mathrm{C})$ index is based on robust estimates of $\mu$ and $S$ that are calculated using the algorithm for fast estimation of the minimum covariance determinant (Fast-MCD) by Rousseeuw and Van Driessen (1999), which can provide reliable robust estimates of $\mu$ values and $S$ in datasets contaminated with potential outliers (for details see: Hubert and Debruyne 2010; Rousseeuw and Van Driessen 1999). The D-A-(C) index is then simply the $M D$ calculated for a given sample based on these robust estimates. Robust estimates of $\mu$ and $S$ for the calculation of the D-A-(C) index were computed using the implementation of Fast-MCD in the 'covMcd' function of the 'robustbase' R package ( $v$ 0.93-6; Maechler et al. 2020). All variables were $\log _{10^{-}}$ transformed prior to the calculation to yield a normal data distribution.

\subsection{Testing the sensitivity of the D-A-(C) Index with three approaches}

The data set at hand was analyzed in three different ways:

(1) First, we took an unguided approach to identify differences within this large data set of different water body types. We did not make any assumptions about the ecological condition of the groundwater and simply applied the Fast-MCD algorithm to the full dataset regardless of location, or land use categories. The D-A-(C) was subsequently calculated for each sample based on the resulting robust estimates of $\mu$ and $S$.

(2) As a second approach, we analyzed the data for each sub-region, and land use type separately to take into account regional differences within the data, as we have previously shown that multivariate D-A-(C) fingerprints in groundwater can vary between different geographic regions (Fillinger et al. 2019).

(3) Finally, we illustrated a case where prior expert knowledge of sites is 


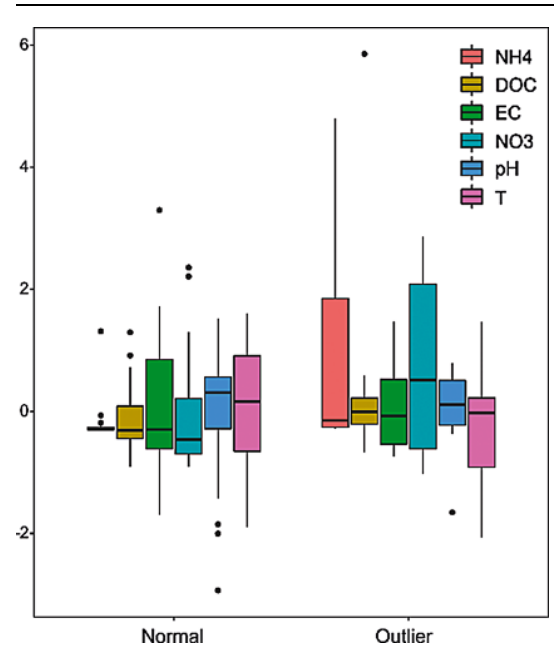

Fig. 3 Boxplot for the $z$-values of the groundwater data set of most commonly measured hydrochemical parameters $\left(\mathrm{NH}_{4}, \mathrm{DOC}, \mathrm{EC}, \mathrm{NO}_{3}, \mathrm{pH}\right.$, and $\left.\mathrm{T}\right)$ for the D-A-C Index calculated according to approach one

used to guide the analysis. For this approach, we defined a reference group of samples which we assumed to be representative of groundwater in the Mur valley under natural or close-to-natural conditions in absence of major anthropogenic impacts. This reference group consisted of samples from the Aichfeld sub-region, which were additionally curated by removing samples which showed signs of anthropogenic impacts based on the municipal wastewater index (samples where MWWI $\neq 0$, Table 1), and surface water intrusion based on the stable water isotope data (e.g., evaporation; Fig. 6). Assuming, that this group did not contain outliers, $\mu$ and $S$ were calculated for this group of reference samples directly without using robust estimates from Fast-MCD and subsequently used to calculate the D-A- $(\mathrm{C})$ index as Mahalanobis distances for all remaining groundwater samples relative to this reference group.

\section{Results}

Applying the D-A Index we analyzed our dataset to assess the microbiological-ecological status and a possible ecological disturbance within the individual groundwater samples collected. We further implemented two DOM indices (HIX and BIX) into a D-A-C index. Both the D-A Index and the D-A-C index were performed (1) in an unguided, simple but insensitive manner, (2) with an increased spatial resolution taking sub-regions and land use into account, an (3) in the high-sensitivity mode with application of a reference data set.

\subsection{Approach one: Detecting differences in the full data set without any prior knowledge}

Multivariate plots of the individual samples, as well as the D-A-(C) signatures are here calculated for all samples with respect to the groundwater data set and no prior knowledge (Fig. 2). The plots show the distribution of groundwater and surface water samples in terms of prokaryotic cell numbers and microbial activities. The black, dashed ellipse depicts the 0.975 confidence level of the groundwater data set and shows that river samples clearly cluster separately from groundwater samples. Additionally, if we label the samples according to their affiliation to sub-regions or according to their origin from areas of different land use 'post-analysis', we see that sub-clusters are visible, which indicate that groundwater samples collected from the same sub-regions are more similar to each other than to those of other sub-regions. However, at the same time there is a considerable overlap between the samples of different sub-regions, and land use types. Samples that deviate significantly from the distribution of the groundwater data are considered outliers, and consequently are regarded as 'disturbed' with respect to their overall microbiological-ecological status. Approach one revealed that several river water samples, were classified as outliers, while all but one groundwater sample, two spring water samples and the rest of the river water samples were classified 'undisturbed' by the D-A Index. When having a closer look at the origin of the river sample outliers, they all stem from the lower river Mur sub-regions (i.e., Lower Mur valley, Leibnitzer Feld, Grazer Feld, and Murdurchbruchstal) that experience strong influences from land use and urbanization. The portion of river samples clustering within the confidence ellipse originate from the upper stretch of the Mur river located in the alpine region (i.e., Upper Mur valley, Lungau, Aichfeld), where the morphology and water quality of the river is natural or only moderately anthropogenical impacted. The groundwater samples that group close to these uncontaminated surface water samples can be considered as most contaminated within the groundwater data set, ignoring possible regional or local differences in natural groundwater quality. Besides the D-A Index (Fig. 2b; left), we also calculated the Index further incorporating the DOM humification (HIX) and biological index (BIX) referred to as D-A-C Index (Fig. 2b; right). The D-A-C Index reveals that all surface waters are outliers (rivers and springs), and also some of the further downstream groundwater monitoring wells, as well as wells that have a MWWI $\neq 0$, or are otherwise conspicuous (e.g., samples 86, and 9 have a strikingly high concentration of ammonium (400-500 $\mu \mathrm{g} \mathrm{L}^{-1}$ ), samples 5 and 7 show the highest measured nitrate concentrations $\left(13-15 \mathrm{mg} \mathrm{L}^{-1}\right)$ as is summarized in Fig. 3).

Because no reference data set on the 'good ecological status' was available, the approach introduced here displayed low sensitivity in separating undisturbed from disturbed samples in the group of samples that are more alike. As demonstrated, the D-A Index could not even separate all surface water samples from the groundwater data set. Some river samples were classified as 'undisturbed', although microbiological characteristics of surface waters and natural groundwater typically differ significantly (see discussion below). The D-A-C index performed better and separated all surface waters from groundwaters with physicochemical features that were clearly at the upper end of the variance in measures from the rest of the groundwater samples. In our next approach, we excluded the surface water samples from the analysis and further consider regional differences that may influence groundwater quality and ecological status, such as hydrogeology and land use.

\subsection{Approach two: Detection of disturbed groundwater taking sub- regions and land use into account}

In our second approach, we based the calculation of the D-A-(C) index on our groundwater dataset only, as well as factoring different categories, i.e., the Mur valley's different sub-regions and different land use types into its computation. In approach two, the D-A Index classified five groundwater samples as outliers within the individual sub-regions (Fig. 4a) and one sample within the land use types (Fig. 4b). Further consideration of the HIX and BIX again 

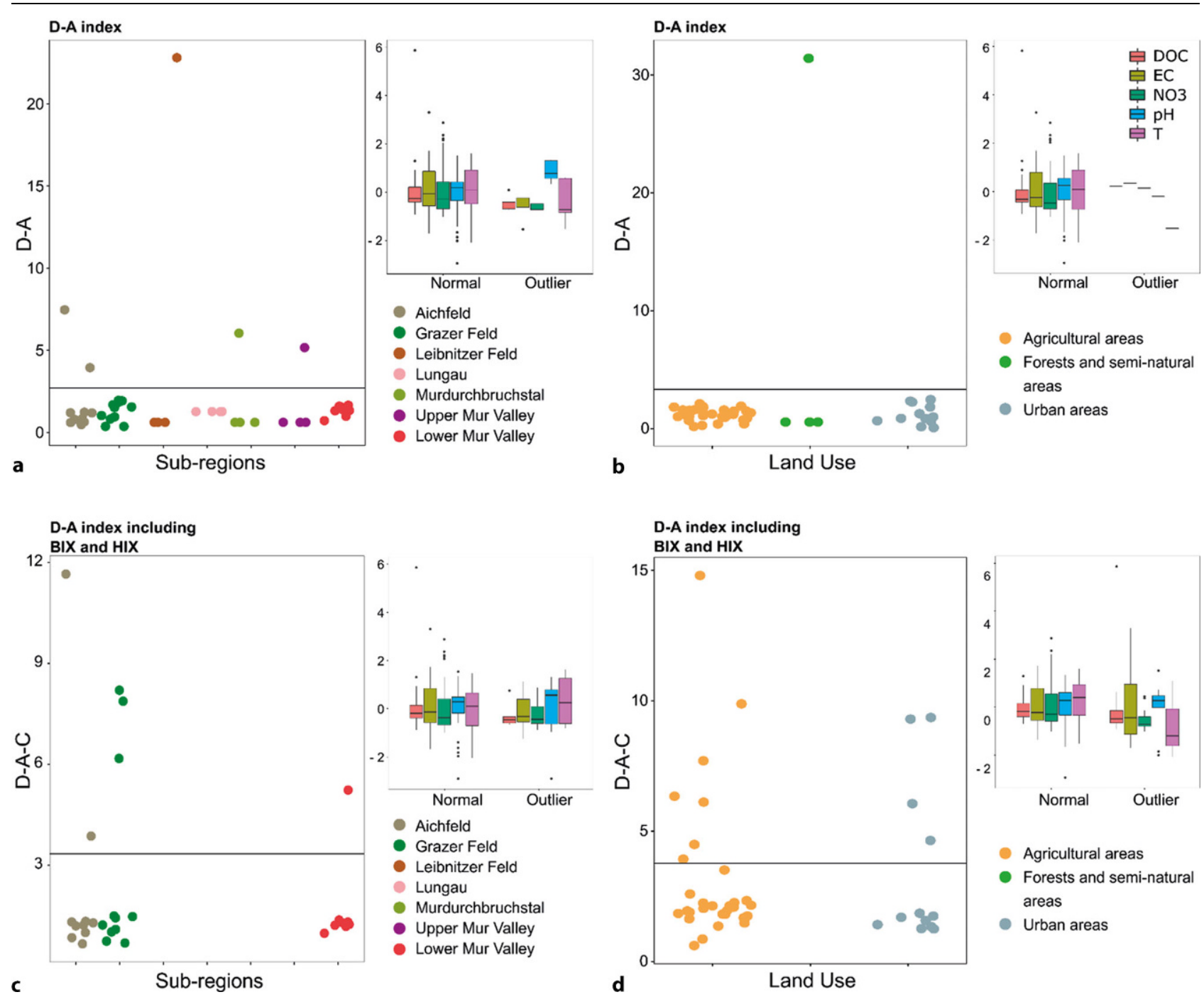

Fig. 4 D-A index (a, b), and D-A-C index (c, d) computed for groundwater samples in reference to their different sub-regions (a, $\mathbf{c})$, as well as land use classifications (b, d). Outliers shown here thus deviate from the regional average of internal ATP, and microbial cell counts, as outlined in the second approach. In every plot the deviation from the mean value of the most commonly measured hydrochemical parameters ( $\mathrm{DOC}, \mathrm{EC}, \mathrm{NO}_{3}, \mathrm{pH}$, and $\mathrm{T}$ ) are illustrated as their z-scores in form of a boxplot. The calculation of the $\mathrm{D}$-A index including HIX and BIX was only possible for 3 subregions (Aichfeld, Grazer Feld, and Lower Mur Valley), and two land use types respectively (Agricultural areas, and Urban areas) due to the insufficient number of samples. The solid black line depicts the critical value of the chi-squared distribution with a confidence level of 0.975 and two degrees of freedom in plot $\mathbf{a}$ and $\mathbf{b}$, and four degrees of freedom in plot c, and d. In all plots, thex-axis shows the data points fanned out into the various sub-categories the index computation was based upon

improved the sensitivity of the assessment, with an increase in the number of outliers (Fig. 4c, d). Still the assessment of disturbed samples from a large set of groundwater samples analyzed was biased. Since approach two again lacked the information on a reference status of undisturbed groundwater, the outliers in our calculations may depict the disturbed samples only in case most other samples are undisturbed. Vice versa, in case most samples analyzed were disturbed, the natural and undisturbed groundwater samples were flagged as outliers. One example is shown in Fig. 4d, where outliers are comprised of those groundwater samples that can be regarded as most undisturbed, as is indicated by the differences in physicochemical parameters. For each plot, the differences between outliers and the remaining data points in relation to the five most commonly measured environmental parameters, namely DOC, electric conductivity, nitrate, $\mathrm{pH}$, and temperature (the entire set of measured parameters can be found in Table 1) are shown. Most of the outlier samples not only differed in D-A-C but also in their physico-chemical pattern. Worth mentioning, since the group of samples that can be analyzed in each category (subregion and land use type) must at least contain one data point more than there are variables in the index calculation, the D-A-C index could be calculated for only three sub-regions (Fig. 4c) and two land use types (Fig. 4d). For a maximum sensitivity of the D-A-(C) Index, we introduce one well defined reference data set in the next step of analysis, i.e. approach three. 

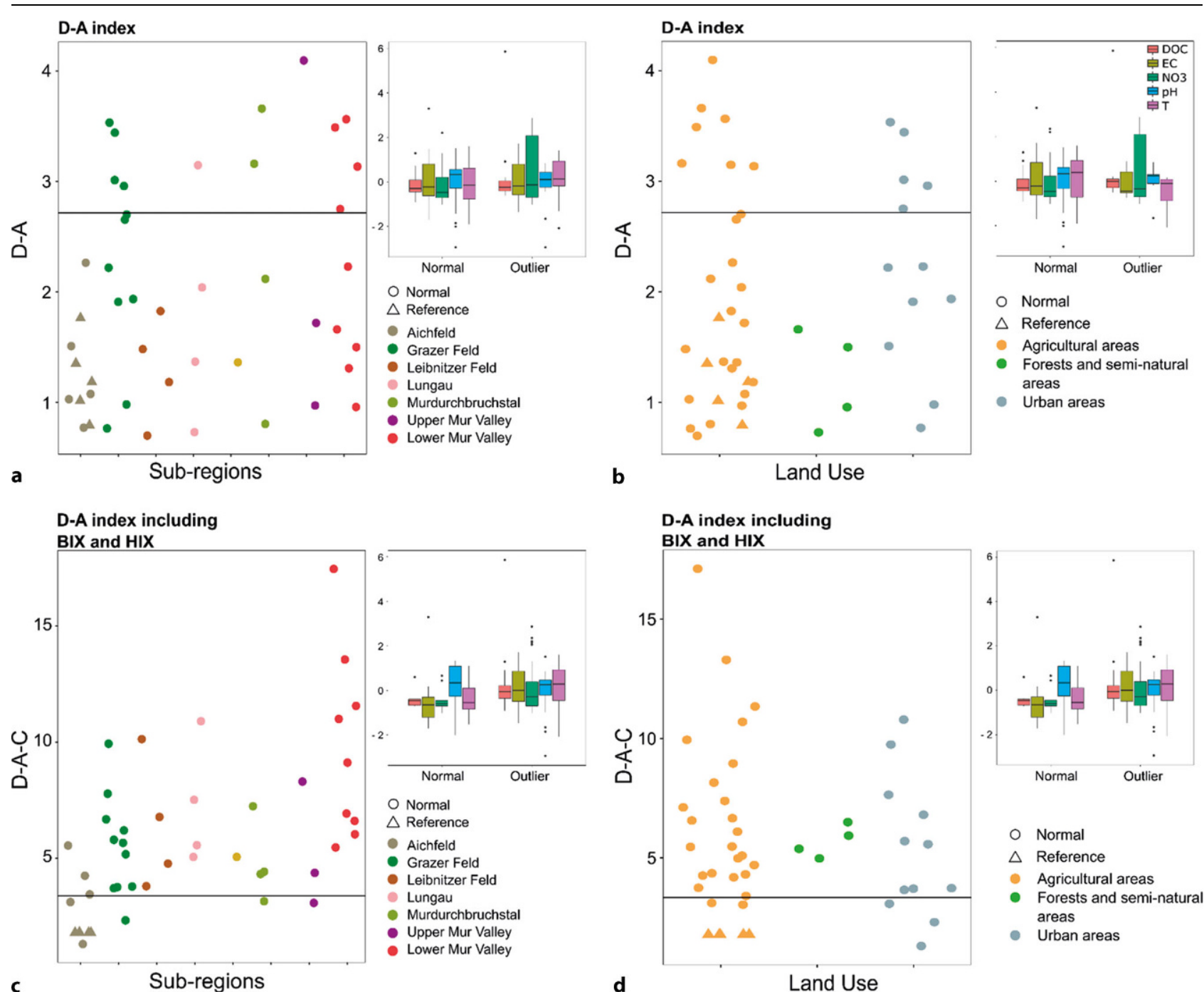

b

Land Use

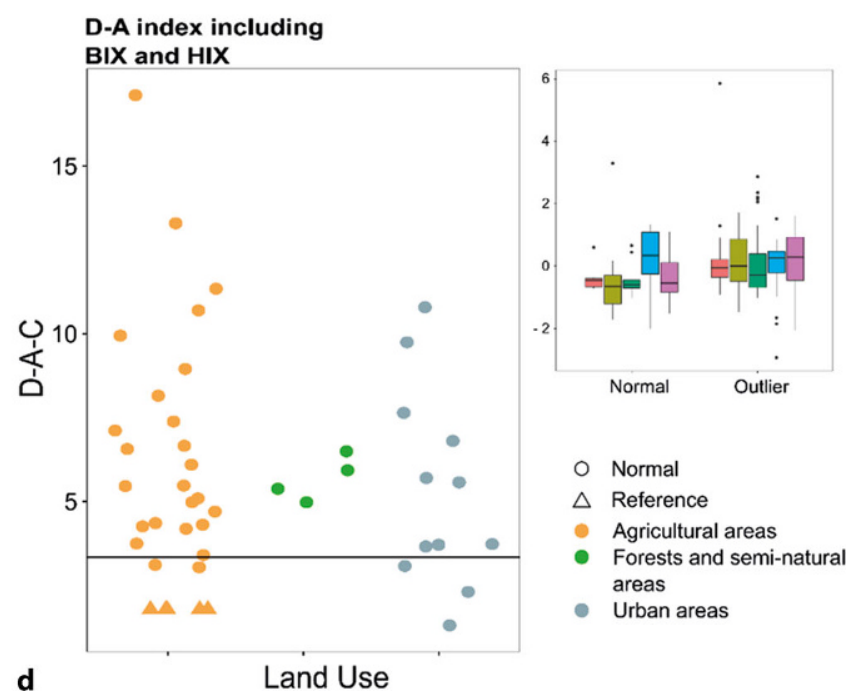

Fig. 5 D-A index (a, b), and D-A-C index (c, d) computed for groundwater samples in reference to their different sub-regions (a, c), as well as land use classifications $(\mathbf{b}, \mathbf{d})$. Outliers shown here thus deviate from a unique pristine reference group in terms of internal ATP, and microbial cell counts, as outlined in the third approach. In every plot the deviation from the mean value of the most commonly measured hydrochemical parameters ( $\mathrm{DOC}, \mathrm{EC}, \mathrm{NO}_{3}, \mathrm{pH}$, and $\mathrm{T}$ ) are illustrated as their z-scores in form of a boxplot. The solid black line depicts the critical value of the chi-squared distribution with a confidence level of 0.975 and two degrees of freedom in plot $a$ and b, and four degrees of freedom in plot c, and d. In all plots, the $\mathrm{x}$-axis shows the data points fanned out into the various sub-categories the index computation was based upon

\subsection{Approach three: Detection of} disturbed groundwater samples integrating pre-existing expert knowledge

As in approach two, the inclusion of HIX and BIX increased the number of outliers (Fig. 5) for approach three. Similarly, the physico-chemical parameters of the outliers appeared to be slightly different from the other 'undisturbed' samples, i.e. they tended to be higher in temperature, electrical conductivity, nitrate and DOC, but lower in $\mathrm{pH}$, which permits the assumption that the groundwaters identified as outliers here were in fact influenced or disturbed in some way. In other words, in contrast to approach two, the outliers here formed the group of disturbed groundwater samples. Moreover, when comparing the D-A-C index results from approaches two and three, the number of disturbed groundwater samples in this comprehensive data set now outnumbered the number of 'good', uncontaminated groundwater samples. Thus, the availability of a reliable reference data set and the inclusion of HIX and BIX can in fact noticeably increase the sensitivity of analysis (Fig. 5).

\section{Discussion}

Aquifers harbor diverse organismic communities, microorganisms and metazoans, which are essential to providing pivotal ecosystem services (Griebler and Avramov 2015). In the recent past, an increasing awareness of the 'ecological' characteristics of groundwater could be noticed, underlined by the numerous targeted international and national research projects that have been funded (e.g. AQUALIFE 2020; GroundCare 2020), scientific reports and papers that have been recently published (e.g. Griebler et al. 


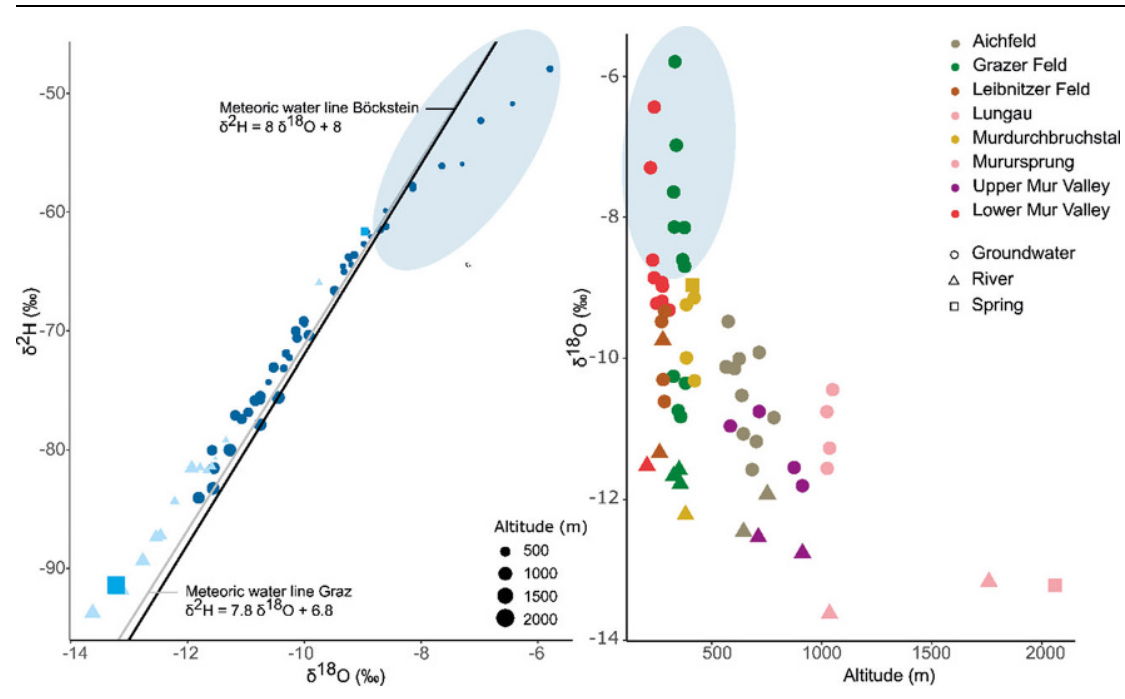

Fig. 6 Bivariate plot of isotope data of the full dataset. The blue ellipse marks those samples which lie below the regional meteoric water lines of Graz (alpine foreland) and Böckstein (alpine region) and are therefore probably affected by evaporation. Local meteoric water lines for Austria were taken from Hager and Foelsche (2015)

2014b; Korbel and Hose 2017; Griebler et al. 2018; Fillinger et al. 2019; di Lorenzo et al. 2020), and novel directives that have been implemented (Hahn et al. 2018). The D-A-(C) index is one of the various tools that have recently been developed for the easy, fast, and inexpensive assessment of the groundwater microbiologicalecological status (Fillinger et al. 2019). Here, we elaborate the applicability of the D-A-(C) Index considering different frame conditions.

The D-A-(C) Index can be easily applied to every kind of data set, with the restriction that the data group to be analyzed needs to be larger than the measures implemented in the index. However, as obvious from the results obtained by 'approach one' (uninformed and unguided evaluation), the size of the data set as well as the distribution of undisturbed and disturbed samples in the data group strongly influence the outcome of the analysis. Without consideration of spatial heterogeneities (e.g. appropriate local to regional resolution) and temporal variabilities (e.g. seasonality), as well as without the availability of a well-defined reference data set, the index cannot discriminate between 'good' and 'bad', and between 'very good' and 'less good' in terms of the microbiological-ecological status. This approach is useful to evaluate differences in space and follow changes over time, but is seen as only a very first step. Already, consideration of local and regional particularities, such as hydrogeological conditions, increase the discrimination power of the index significantly. However, a reliable separation of groundwater that exhibits a natural or close-to-natural ecological status and groundwater that shows signs of an ecological disturbance, is only possible with a reference data set in hand.

The delineation of a perfect reference data set is challenging. Without a doubt, available knowledge on physico-chemical conditions, possible anthropogenic and natural influences, as well as expert knowledge are important ingredients. The question is, how specific a reference data set needs to be. Which resolution and sensitivity in the groundwater quality assessment is approached. With different spatial scale, different drivers are active. While on the local scale within an individual groundwater body, key drivers are land use and the distance to the next surface water. On the regional scale, the type of aquifer (porous, fissured or karstic) and the hydraulic connectivity comes into play. At the supra-regional (national, continental, global) scale climate and earth history (e.g. ice ages) did and still do play a major role in shaping groundwater systems.

A first step in defining reference conditions at a spatial scale can be the classification of groundwater systems based on the aquifer type and specific hydrogeological units (e.g. Weitowitz et al. 2017). Subsequently, natural (pristine) and unpolluted representa- tive sites are then selected within each unit (Korbel and Hose 2011, 2017). Importantly, few if any sites or regions on the planet remain unaffected by human activities, such that 'pristine' and 'natural' sites may be unavailable, and reference sites may be based on relatively undisturbed or 'best available' sites (Bailey et al. 2004). In practice, one may consider spots in protected areas (e.g. nature reserve, drinking water protection zones) or high alpine regions that experience less anthropogenic impacts. Robust classifications require adequate assessment of the natural variation within and between units, and may require intensive sampling of a large number of sites to adequately identify site 'types' and characterize the reference condition state (Hose et al. 2020). Complicating the definition of reference conditions is the natural heterogeneity in the subsurface. Among the hydrochemical conditions, oxygen is a key factor that shapes groundwater communities and influences biological processes. Also regional temperature anomalies must be considered. In lack of location- or region-specific knowledge, reference conditions and data sets can alternatively be delineated using national groundwater quality standards and guidelines. A clear advantage of such an individual assembly of a reference data set is that there is always the possibility to upscale the already established reference group in order to improve or counter-adjust it as was done in this paper.

At the moment, the multivariate analysis is still based on very general factors, some of which may correlate with each other. As exemplified with the establishment of the D-A-C index in this study, it may be useful to include other parameters in the assessment to better evaluate the qualitative and ecological status of groundwater. However, it is also important to mention that there are clear limits to the sensitivity of our index with respect to groundwater microbiological-ecological conditions. Any disturbances that do not affect microbes in terms of biomass standing stock, growth and physiological activity cannot be detected. Such disturbances may include the presence of pollutants in trace concentrations (Meckenstock et al. 2015) or moderate temperature alterations (Griebler et al. 2016). Certain limitations in this regard may indeed be overcome by including fluorescence spectroscopy data 
of DOM in the analysis, which may detect traces of organic pollutants under certain conditions (Wasswa et al. 2019). Disturbances resulting from other types of contaminants such as traces of heavy metals, as well as moderate changes in temperature, however, will be more difficult to capture if they do not significantly affect microbial cell numbers or activity levels. Hence, it is important to note that the ecological assessment provided by the D-A(C) index is not intended to replace existing physicochemical (Steinbacher et al. 2021) analyses in groundwater. Rather, the approach is to be used as an amendment to current monitoring approaches in order to provide a more holistic assessment of groundwater that captures its chemical as well as biological-ecological status.

Acknowledgements This work is part of the project 'Integrative Groundwater Assessment' funded by the Earth
System Sciences (ESS) research program of the Austrian Academy of Sciences (ÖAW). We thank Peter Rauch, Barbara Stromberger (Steiermärkische Landesregierung), Harald Huemer and Margot Geiger-Kaiser (Salzburger Landesregierung), for their valuable information and help in selecting appropriate groundwater sampling wells. We thank Sandra Kulscar und Michael Roll (Umweltbundesamt $\mathrm{GmbH}$ ) for the analysis of the municipal waste water indicators. Finally, we deeply acknowledge the fire brigade of Mureck that have literally pulled us out of the mud in the Mur riparian forest.

Funding Open access funding provided by University of Vienna.

\section{Conflict of interest}

A. Retter, C. Griebler, J. Haas, S. Birk, C. Stumpp, H. Brielmann and L. Fillinger declare that they have no competing interests.

Open Access This article is licensed under a Creative Commons Attribution 4.0 International License, which permits use, sharing, adaptation, distribution and reproduction in any medium or format, as long as you give appropriate credit to the original author(s) and the source, provide a link to the Creative Commons licence, and indicate if changes were made. The images or other third party material in this article are included in the article's Creative Commons licence, unless indicated otherwise in a credit line to the material. If material is not included in the article's Creative Commons licence and your intended use is not permitted by statutory regulation or exceeds the permitted use, you will need to obtain permission directly from the copyright holder. To view a copy of this licence, visit http:// creativecommons.org/licenses/by/4. $0 /$
AQUALIFE (2020). Development of an innovative and user-friendly indicator system for biodiversity in groundwater dependent ecosystems. EU project LIFE12 BIO/IT/000231, accessed 14.12.2020at https://ec.europa.eu/ environment/life/project/Projects/index.cfm? fuseaction=search.dspPage\&n_proj_id $=4519$ Bailey, R.C., Norris, R.H., and Reynoldson, T.B (2004). Bioassessment of Freshwater Ecosystems: Using the Reference Condition Approach. Springer, New York.

Benk, S.A., Yan, L., Lehmann, R., Roth, V.N. Schwab, V.F., Totsche, K.U., Küsel, K., and Gleixner, G. (2019). Fueling Diversity in the Subsurface: Composition and Age of Dissolved Organic Matter in the Critical Zone. Front. Earth Sci. 7, 1-12.

Brielmann, H., Griebler, C., Schmidt, S.I. Michel, R., and Lueders, T. (2009). Effects of thermal energy discharge on shallow groundwater ecosystems. FEMS Microbiol. Ecol. 68, 273-286.

Coble, P.G., Lead, J., Baker, A., Reynolds, D.M. and Spencer, R.G.M. (2014). Aquatic Organic Matter Fluorescence (New York: Cambridge University Press).

Corada-Fernández, C., Candela, L., TorresFuentes, N., Pintado-Herrera, M.G., Paniw, M., and González-Mazo, E. (2017). Effects of extreme rainfall events on the distribution of selected emerging contaminants in surface and groundwater: The Guadalete River basin (SW, Spain). Sci. Total Environ. 605-606, 770-783.

Di Lorenzo, T., Fiasca, B., Di Camillo Tabilio, A., Murolo, A., Di Cicco, M., and Galassi, D.M.P. (2020). The weighted Groundwater Health Index (wGHI) by Korbel and Hose (2017) in European groundwater bodies in nitrate vulnerable zones. Ecol. Indic. 116, 106525. https://doi.org/10. 1016/j.ecolind.2020.106525

Fillinger, L., Hug, K., Trimbach, A.M., Wang, H.,

Kellermann, C., Meyer, A., Bendinger, B., and
Griebler, C. (2019). The D-A-(C) index: A practical approach towards the microbiological-ecological monitoring of groundwater ecosystems. Water Res. 163, 114902.

Frank, S., Goeppert, N., and Goldscheider, N. (2018). Fluorescence-based multi-parameter approach to characterize dynamics of organic carbon, faecal bacteria and particles at alpine karst springs. Sci. Total Environ. 615, 1446-1459. Gibert, J., and Culver, D.C. (2009). Assessing and conserving groundwater biodiversity: an introduction. Freshw. Biol. 54, 639-648.

Gooddy, D.C., and Hinsby, K. (2009). Organic Quality of Groundwaters. In Natural Groundwater Quality, (Oxford: Blackwell Publishing), pp. 59-70.

Griebler, C., and Avramov, M. (2015). Groundwater ecosystem services: A review. Freshw. Sci. $34,355-367$.

Griebler, C., and Lueders, T. (2009). Microbial biodiversity in groundwater ecosystems. Freshw. Biol. 54, 649-677.

Griebler, C., Brielmann, H., Haberer, C.M. Kaschuba, S., Kellermann, C., Stumpp, C., Hegler, F., Kuntz, D., Walker-Hertkorn, S. and Lueders, T. (2016). Potential impacts of geothermal energy use and storage of heat on groundwater quality, biodiversity and ecosystem processes. Environ. Earth Sci. 75, 1391.

Griebler, C., Hug, K., Fillinger, L., Meyer, A. and Avramov, M. (2018). Der B-A-E Index Ein mikrobiologisch-ökologisches Konzept zur Bewertung und Überwachung von Grundwasse (The B-A-E Index - a microbiological-ecological concept for the assessment and monitoring of groundwater). Hydrologie \& Wasser 62, 6-14. Griebler, C., Malard, F., and Lefébure, T. (2014a). Current developments in groundwater ecologyfrom biodiversity to ecosystem function and services. Curr. Opin. Biotechnol. 27, 159-167.

Griebler, C., Stein, H., Kellermann, C., Berkhoff,

S., Brielmann, H., Schmidt, S.I., Selesi, D.
Steube, C., Fuchs, A., and Hahn, H.J. (2010). Ecological assessment of groundwater ecosystems - vision or illusion? Ecol. Engineer. 36, 1174-1190.

Griebler, C., Hahn, H.J., Stein, H., Kellermann, C., Fuchs, A., Steube, C., Berkhoff, S., and Brielmann, H. (2014b). Entwicklung biologischer Bewertungsmethoden und -kriterien für Grundwasserökosysteme (Development of biological assessment methods and criteria for groundwater ecosystems). UFOPLAN, FKZ 370823200 , ISSN: 1862-4804, $153 \mathrm{~S}$.

GroundCare (2020). Parameterisation and quantification of ecosystem services as a basis for sustainable groundwater management. German BMBF Project, accessed 14.12.2020, at https://bmbf.nawam-rewam.de/en/projekt/ groundcare/

Haas, J.C., and Birk, S. (2017). Characterizing the spatiotemporal variability of groundwater levels of alluvial aquifers in different settings using drought indices. Hydrol. Earth Syst. Sci. 21, 2421-2448.

Hager, B., and Foelsche, U. (2015). Stable isotope composition of precipitation in Austria. Austrian J. Earth Sci. 108, 2-14.

Hahn, H.J. (2006). The GW-Fauna-Index: A first approach to a quantitative ecological assessment of groundwater habitats. Limnologica 36 119-137.

Hahn, H.J., Schweer, C., and Griebler, C. (2018). Grundwasserökosysteme im Recht? - Eine kritische Betrachtung zur rechtlichen Stellung von Grundwasserökosystemen (Groundwater ecosystems rights considered? - A critical evaluation of the legal background of groundwater ecosystems) Grundwasser 23, 209-218.

Hammes, F.A., and Egli, T. (2005). New method for assimilable organic carbon determination using flow-cytometric enumeration and a natural microbial consortium as inoculum. Environ. Sci. Technol. 39, 3289-3294. 
Hammes, F., Goldschmidt, F., Vital, M., Wang, Y., and Egli, T. (2010). Measurement and interpretation of microbial adenosine tri-phosphate (ATP) in aquatic environments. Water Res. 44, 3915-3923.

Harjung, A., Attermeyer, K., Aigner, V., Krlovic, N., Steniczka, G., Švecová, H., Schagerl, M. and Schelker, J. (2020). High Anthropogenic Organic Matter Inputs during a Festival Increase River Heterotrophy and Refractory Carbon Load. Environ. Sci. Technol. 54, 10039-10048.

Hassane, A.B., Leduc, C., Favreau, G., Bekins, B.A., and Margueron, T. (2016). Impacts of a large Sahelian city on groundwater hydrodynamics and quality: example of Niamey (Niger). Hydrogeol. J. 24, 407-423.

Herman, J.S., Culver, D.C., and Salzman, J. (2001). Groundwater Ecosystems and the Service of Water Purification. Stanford Environ. Law J. 20, 479-496.

Hofmann, R., Uhl, J., Hertkorn, N., and Griebler, C. (2020). Linkage Between Dissolved Organic Matter Transformation, Bacterial Carbon Production, and Diversity in a Shallow Oligotrophic Aquifer: Results From Flow-Through Sediment Microcosm Experiments. Front. Microbiol. 11, 543567. https://doi.org/10.3389/fmicb.2020. 543567

Hose, G.C., Di Lorenzo, T., Fillinger, L., Galassi, D.M.P., Griebler, C., Hahn, H.J., Handley, K.M. Korbel, K., Reboleira, A.S., Siemensmeyer, T., Spengler, C., Weaver, L., and Weigand, A. (2021). Assessing groundwater ecosystem health, status and services. In 'Groundwater Ecology and Evolution' (Malard, F., Retaux, S. \& Griebler, C., eds.), Elsevier, in press.

Howard, K., and Gerber, R. (2018). Impacts of urban areas and urban growth on groundwate in the Great Lakes Basin of North America. J. Great Lakes Res. 44, 1-13.

Hubalek, V., Wu, X., Eiler, A., Buck, M., Heim, C., Dopson, M., Bertilsson, S., and Ionescu, D. (2016). Connectivity to the surface determines diversity patterns in subsurface aquifers of the Fennoscandian shield. ISME J. 10, 2447-2458. Hubert, M., and Debruyne, M. (2010). Minimum covariance determinant. Wiley Interdiscip. Rev. Comput. Stat. 2, 36-43.

Huguet, A., Vacher, L, Relexans, S., Saubusse, S., Froidefond, J.M., and Parlanti, E. (2009) Properties of fluorescent dissolved organic matter in the Gironde Estuary. Org. Geochem. 40, 706-719.

Khan, M.N., Mobin, M., Abbas, Z.K., and Alamri, S.A. (2018). Fertilizers and their contaminants in soils, surface and groundwater. In The Encyclopedia of the Anthropocene, (Oxford: Elsevier Inc.), pp. 225-240.

Korbel, K.L., and Hose, G.C. (2011). A tiered framework for assessing groundwater ecosystem health. Hydrobiologia 661, 329-349.

Korbel, K.L., and Hose, G.C. (2017). The weighted groundwater health index: Improving the monitoring and management of groundwater resources. Ecol. Indic. 75, 164-181.

Lee, H.J., Kim, K.Y., Hamm, S.Y., Kim, M.S. Kim, H.K., and Oh, J.E. (2019). Occurrence and distribution of pharmaceutical and persona care products, artificial sweeteners, and pesticides in groundwater from an agricultural area in Korea. Sci. Total Environ. 659, 168-176. Di Lorenzo, T., Fiasca, B., Di Camillo Tabilio A., Murolo, A., Di Cicco, M., and Galassi, D.M.P. (2020b). The weighted Groundwater Health Index (wGHI) by Korbel and Hose (2017) in European groundwater bodies in nitrate vulnerable zones. Ecol. Indic. 116, 106525.

Meckenstock, R.U., Elsner, M., Griebler, C. Lueders, T., Stumpp, C., Dejonghe, W., Bastiaens, L., Sprigael, D., Smolders, E., Boon, N., Agathos, S., Sorensen, S.R., Aamand, J., Albrechtsen, H.-J., Bjerg, P., Schmidt, S.I., Huang, W., and van Breukelen, B. (2015). Biodegradation: Updating the concepts of control for microbial clean-up in contaminated aquifers. Environ. Sci. Technol. 49, 7073-7081.

Menchen, A., Heras, J.D. las, and Alday, J.J.G. (2017). Pesticide contamination in groundwate bodies in the Júcar River European Union Pilot Basin (SE Spain). Environ. Monit. Assess. 189, 146. https://doi.org/10.1007/s10661-017-5827-

Minnig, M., Moeck, C., Radny, D., and Schirmer, M. (2018). Impact of urbanization on groundwater recharge rates in Dübendorf, Switzerland. J. Hydrol. 563, 1135-1146.

Nowicki, S., Lapworth, D.J, Ward, J.S.T, Thom son, P., and Charles, K. (2019). Tryptophan-like fluorescence as a measure of microbial contamination risk in groundwater. Sci. Total Environ. 646, 782-791.

Ohno, T. (2002). Fluorescence inner-filtering correction for determining the humification in dex of dissolved organic matter. Environ. Sci. Technol. 36, 742-746.

Pucher, M., Wünsch, U., Weigelhofer, G., Murphy, K., Hein, T, and Graeber, D. (2019). StaRdom: Versatile software for analyzing spectroscopic data of dissolved organic matter in $\mathrm{R}$. Water (Switzerland) 11, 1-19.

Rehman, F., and Cheema, T. (2016). Effects of sewage waste disposal on the groundwater quality and agricultural potential of a floodplain near Jeddah, Saudi Arabia. Arab. J. Geosci. 9, 307 https://doi.org/10.1007/s12517-016-2340-y

Ribeiro, L., Stigter, T.Y., Chambel, A., Condesso de Melo, M.T., Monteiro, J.P., and Medeiros, A (2013). Groundwater and ecosystems (London: CRC Press).

Rousseeuw, P.J., and Van Driessen, K. (1999). A fast algorithm for the minimum covariance determinant estimator Technometrics 41 , 212-223.

Shen, Y., Chapelle, F.H., Strom, E.W., and Benner, R. (2015). Origins and bioavailability of dis- solved organic matter in groundwater. Biogeochemistry 122, 61-78.

Singh, S., Raju, N.J., Gossel, W., and Wycisk, P. (2016). Assessment of pollution potential of leachate from the municipal solid waste disposal site and its impact on groundwater quality, Varanasi environs, India. Arab. J. Geosci. 9, 1-12. Sorensen, J.P.R., Lapworth, D.J., Nkhuwa, D.C.W., Stuart, M.E., Gooddy, D.C., Bell, R.A. Chirwa, M., Kabika, J., Liemisa, M., Chibesa, M. et al. (2015). Emerging contaminants in urban groundwater sources in Africa. Water Res. 72, 51-63.

Sorensen, J.P.R., Carr, A. F, Nayebare, J., Diongue, D.M.L., Pouye, A, Roffo, R., Gwengweya, G., Ward, J.S.T., Kanoti, J., Okotto-Okotto, J. et al. (2020). Tryptophan-like and humic-like fluorophores are extracellular in groundwater: implications as real-time faecal indicators. Sci. Rep. 10, 1-9.

Spandl, H. (1926). Wissenschaftliche Forschungsergebnisse aus dem Gebiete der unteren Donau und des Schwarzen Meeres. II. Die Süßwasser-Mikrofauna [Scientific research results from the areas of the lower Danube and the Black Sea. II. The freshwater microfauna]. Archiv fur Hydrobiologie 16: 528-604.

Steinbacher, S.D., Savio, D., Demeter, K., Karl, M., Wolfgang, K., Kirschner, A.K.T., Reischer, G.H., Ixenmaier, S.K., Mayer, R.E., Mach, R.L., Derx, J., Sommer, R., Linke, R. and Farnleitner, A.H. (2021). Genetic microbial faecal source tracking: rising technology to support water quality testing and safety management of the future. Österreichische Wasser-und Abfallwirtschaft.

Steube, C., Richter, S., and Griebler, C. (2009). First attempts towards an integrative concept for the ecological assessment of groundwater ecosystems. Hydrogeol. J. 17, 23-35.

Ward, N.D., Bianchi, T.S., Medeiros, P.M., Seidel, M., Richey, J.E., Keil, R.G., and Sawakuchi, H.O. (2017). Where Carbon Goes When Water Flows: Carbon Cycling across the Aquatic Continuum. Front. Mar. Sci. 4, 1-28.

Wasswa, J., Mladenov, N., and Pearce, W. (2019) Assessing the potential of fluorescence spectroscopy to monitor contaminants in source waters and water reuse systems. Environ. Sci. Water Res. 5, 370-382.

Weitowitz, D.C., Maurice L., Lewis, M., Bloomfield, J.P., Reiss, J., and Robertson, A.L. (2017). Defining geo-habitats for groundwater ecosystem assessments: an example from England and Wales (UK). Hydrogeol. J. 25, 2453-2466.

Publisher's Note Springer Nature remains neutral with regard to jurisdictional claims in published maps and institutional affiliations. 